\title{
Combined use of cytological, visual and colposcopic examination for evaluation of unhealthy cervix and their histopathological correlation
}

\author{
Deepak Patil, B. Pathak*
}

Department of Obstetrics and Gynaecology, Command Hospital Air Force Bangalore, Bangalore, Karnataka, India

Received: 12 April 2021

Revised: 29 April 2021

Accepted: 30 April 2021

\section{*Correspondence:}

Dr. B. Pathak,

E-mail: bpathak_go@yahoo.co.in

Copyright: ( $)$ the author(s), publisher and licensee Medip Academy. This is an open-access article distributed under the terms of the Creative Commons Attribution Non-Commercial License, which permits unrestricted non-commercial use, distribution, and reproduction in any medium, provided the original work is properly cited.

\begin{abstract}
Background: Unhealthy cervix can be a presentation of a broad spectrum of clinical conditions with diverse pathologies like infective, inflammatory, reactive and neoplastic etc. Cervical cancer, having a multifactorial causation, is the second most common cancer in female population. Because of a prolonged preinvasive phase, the cancer can be diagnosed at an earlier stage. Early diagnosis makes it amenable to treatment.

Methods: A total 100 ladies attending gynaecology OPD of a tertiary care teaching hospital with unhealthy cervix were evaluated. It involved history taking, cytological assessment by Pap smear, examination of cervix after acetic acid application (VIA), colposcopic assessment and biopsy for histopathological evaluation.

Results: Correlation of all these modalities to rule out neoplastic aetiology showed a high specificity of $91.9 \%$. The positive predictive value of combined approach was found to be $65 \%$ whereas negative predictive value approached $100 \%$.

Conclusions: Combined approach with VIA, Colposcopy, Pap smear and Directed biopsy provide a comprehensive evaluation of unhealthy cervix.
\end{abstract}

Keywords: Unhealthy cervix, Colposcopy, Histopathology, Pap smear

\section{INTRODUCTION}

Unhealthy cervix may result from various causative factors. Cervix is constantly exposed to physiological changes, cellular organisation with age, infective aetiologies along with exposure to environmental factors. All these make cervical tissue prone to infection, inflammation and neoplastic changes.

Cervical cancer may present as unhealthy cervix at an early stage. With improvement in awareness, screening programs and preventive measures, incidence of cervical cancer continues to decrease in both developed and developing countries. However, in developing nations like India, it continues to be diagnosed at more advanced stages. Approximately $90 \%$ of new cases are occurring in developing countries lacking an organised screening programmes. ${ }^{1}$

The objective of the study was to see the effectiveness of combined use of various screening modalities for unhealthy cervix.

\section{METHODS}

This prospective observational study was conducted during January 2004 and December 2005 in Command Hospital, Pune, a tertiary care teaching hospital with 100 patients with unhealthy cervix. Patients in the age group of 20 to 60 years with unhealthy cervix were included 
whereas patients with obvious neoplastic growth, history of prior cervical surgery and pregnancy were excluded from the study. All the participants were subjected to all the tests.

Ethical approval was taken from the Institutional Ethics Committee.

After counselling and taking written consent, pap smears were taken by conventional method by using Ayres spatula and cytobrush for ectocervix and endocervix respectively. Reports were graded as per Bethesda System of classification.

VIA (Visual Inspection after Acetic acid application) was done using 5\% solution of Acetic acid. Aceto white areas were mapped and directed biopsy were taken.

Kaps mobile Colposcope of $300 \mathrm{~mm}$ focal length with swing-in green filter was used for Colposcopy. After applying Cusco's speculum, entire transformation zone was assessed. Suspicious area with exaggerated vascular pattern was re-evaluated in green filter. Directed biopsy from these areas were taken and sent in $10 \%$ formalin. Statistical analysis was done using chi square test.

\section{RESULTS}

\section{Age and parity of participants}

Maximum participants (total 36) were in the age group of 30 to 35 years. The maximum parity (total 36) amongst the participants was Para 3 (Table 1).

Table 1: Age and parity distribution of participants.

\begin{tabular}{|lllll|}
\hline \multicolumn{2}{|l}{ Age groups } & \multicolumn{3}{c|}{ Parity } \\
\hline $\begin{array}{l}\text { Sr. } \\
\text { No. }\end{array}$ & $\begin{array}{l}\text { Age group } \\
\text { (years) }\end{array}$ & Number & Parity & Number \\
\hline $\mathbf{1}$ & $20-25$ & 5 & Nullipara & 2 \\
\hline $\mathbf{2}$ & $25-30$ & 10 & Para 1 & 10 \\
\hline $\mathbf{3}$ & $30-35$ & 36 & Para 2 & 32 \\
\hline $\mathbf{4}$ & $35-40$ & 16 & Para 3 & 36 \\
\hline $\mathbf{5}$ & $40-45$ & 11 & Para 4 & 16 \\
\hline $\mathbf{6}$ & $45-50$ & 16 & Para 5 & 4 \\
\hline $\mathbf{7}$ & $50 \mathrm{y}+$ & 6 & & \\
\hline
\end{tabular}

\section{Presenting complaints and clinical diagnosis}

Majority of the participants presented with white discharge (51) followed by menstrual complaints (26). However, many presented with multiple complaints. Unhealthy cervix (52) was the most common clinical finding followed by erosion of cervix (33) (Table 2).

\section{HPE evaluation}

All cases were subjected to HPE. Out of 100 cases, 13 were positive and 87 were negative on HPE.

\section{Colposcopic evaluation}

Colposcopic evaluation was done for all participants. Out of 100 participants 88 had satisfactory evaluation out of which 37 had normal finding, 32 had atypical transformation zone and 19 had inflamed cervix. Total 36 had atypical colposcopic finding (Table 3 ).

Table 2: Presenting complaints of participants.

\begin{tabular}{|llll|}
\hline Presenting complaints & & Clinical diagnosis \\
\hline Whitish discharge & 51 & Erosion of cervix & 33 \\
\hline Post coital bleeding & 5 & Unhealthy cervix & 52 \\
\hline Menstrual complaint & 26 & Cervicitis & 15 \\
\hline Pain abdomen & 6 & & \\
\hline Dyspareunia & 8 & \\
\hline Routine screening & 4 & \\
\hline
\end{tabular}

Table 3: Colposcopic findings.

\begin{tabular}{|c|c|c|c|}
\hline \multicolumn{2}{|l|}{ Category } & \multicolumn{2}{|c|}{ Colposcopic findings } \\
\hline \multirow{3}{*}{ Satisfactory } & \multirow{3}{*}{88} & Normal study & 37 \\
\hline & & $\begin{array}{l}\text { Atypical } \\
\text { transformation zone }\end{array}$ & 32 \\
\hline & & $\begin{array}{l}\text { Inflammatory } \\
\text { cervix }\end{array}$ & 19 \\
\hline \multirow{4}{*}{$\begin{array}{l}\text { Atypical } \\
\text { colposcopic } \\
\text { findings }\end{array}$} & \multirow{4}{*}{36} & Acetowhite areas & 18 \\
\hline & & Abnormal vessels & 8 \\
\hline & & Punctations & 6 \\
\hline & & Mosaics & 4 \\
\hline
\end{tabular}

Table 4: Colposcopic Evaluation and correlation with malignancy.

\begin{tabular}{|llll|}
\hline \multirow{2}{*}{ Colposcopy } & \multicolumn{2}{l|}{ Malignancy by HPE } \\
& Positive & Negative & Sensitivity \\
Positive (32) & 10 & 22 & $76.9 \%$, \\
Negative (68) & 3 & 65 & Specificity \\
\cline { 1 - 3 } & & & $74 \%$ \\
Total & 13 & 87 & $\begin{array}{l}\text { Positive } \\
\text { predictive } \\
\end{array}$ \\
& & & value $31 \%$ \\
& & $\begin{array}{l}\text { Negative } \\
\text { predictive } \\
\end{array}$ \\
& & & value $95 \%$ \\
\hline
\end{tabular}

On histopathological examination (HPE), 10 out of 32 colposcopy positive cases were found to be malignant, whereas 03 out of 68 colposcopy negative cases were found to be positive for malignancy. Colposcopy on statistical evaluation showed a sensitivity of $76.9 \%$ and a specificity of $74 \%$. This modality of evaluation gave a positive predictive value of $31 \%$ negative predictive value of $95 \%$ (Table 4).

\section{VIA evaluation}

Out of 100 cases, 18 were positive and 82 were negative for VIA. 
Out of 18 positive VIA findings 09 were found to be positive for malignancy on HPE. Out of total 82 cases negative for VIA, 04 were found to be malignant. VIA revealed a sensitivity of $69 \%$ and specificity of $89 \%$. Positive and negative predictive values were 50 and $93 \%$ respectively (Table 5).

Table 5: VIA and correlation with malignancy.

\begin{tabular}{|c|c|c|c|}
\hline \multirow{2}{*}{ VIA } & \multicolumn{3}{|c|}{ Malignancy by HPE } \\
\hline & Positive & Negative & Sensitivity \\
\hline Positive (18) & 9 & 9 & $69.2 \%$ \\
\hline Negative (82) & 4 & 78 & Specificity \\
\hline Total (100) & 13 & 87 & $\begin{array}{l}\text { Positive } \\
\text { predictive } \\
\text { value } 50 \% \\
\text { Negative } \\
\text { predictive } \\
\text { value } 93 \%\end{array}$ \\
\hline
\end{tabular}

Table 6: Pap smear findings.

\begin{tabular}{|c|c|c|c|}
\hline \multirow{2}{*}{ Pap Smear } & \multicolumn{3}{|c|}{ Malignancy by HPE } \\
\hline & Positive & Negative & \multirow{4}{*}{$\begin{array}{l}\text { Sensitivity } \\
61 \%, \\
\text { Specificity } \\
86 \% \\
\text { Positive } \\
\text { predictive } \\
\text { value } 40 \% \\
\text { Negative } \\
\text { predictive } \\
\text { value } 93 \%\end{array}$} \\
\hline Positive (20) & 8 & 12 & \\
\hline $\begin{array}{l}\text { Negative } \\
(\mathbf{8 0})\end{array}$ & 5 & 75 & \\
\hline Total (100) & 13 & 87 & \\
\hline
\end{tabular}

Table 8: Overall findings of Pap smear, VIA, Colposcopy and HPE.

\begin{tabular}{|c|c|c|c|c|c|c|c|c|c|c|c|c|}
\hline \multirow{2}{*}{\multicolumn{2}{|c|}{$\begin{array}{l}\text { Colposcopy } \\
\text { Finding }\end{array}$}} & \multicolumn{5}{|c|}{ Pap Smear } & \multirow{2}{*}{$\begin{array}{l}\text { VIA } \\
\text { POS }\end{array}$} & \multicolumn{5}{|l|}{ HPE } \\
\hline & & Normal & Inf & ASCUS & LSIL & HSIL & & Normal & $\begin{array}{l}\text { Chronic } \\
\text { cervicitis }\end{array}$ & LSIL & HSIL & $\begin{array}{l}\text { Malig- } \\
\text { nancy }\end{array}$ \\
\hline $\begin{array}{l}\text { Abnormal } \\
\text { vessels }\end{array}$ & 3 & - & - & 1 & 1 & 1 & 3 & - & - & 1 & - & - \\
\hline Punctation & 3 & - & - & 2 & 1 & - & 3 & - & - & 1 & - & - \\
\hline Mosaics & 2 & - & - & 1 & 1 & - & 1 & - & - & - & 1 & 1 \\
\hline $\begin{array}{l}\text { Abnormal } \\
\text { vessels and } \\
\text { punctations }\end{array}$ & 4 & - & - & 3 & 1 & 1 & 2 & - & - & 1 & 2 & 1 \\
\hline $\begin{array}{l}\text { Abnormal } \\
\text { vessels and } \\
\text { mosaic }\end{array}$ & 3 & - & - & 1 & 2 & - & 3 & - & - & 2 & - & - \\
\hline $\begin{array}{l}\text { Abnormal } \\
\text { vessels } \\
\text { (Punc and } \\
\text { Mosaics) }\end{array}$ & 3 & - & - & 2 & 1 & 1 & 2 & - & - & 1 & 1 & 1 \\
\hline $\begin{array}{l}\text { Normal } \\
\text { Study }\end{array}$ & 82 & 32 & 32 & & & & 78 & 25 & 62 & & & \\
\hline
\end{tabular}

A high specificity of $91.9 \%$ was found. The positive predictive value on combined approach was found to be

\section{Pap smear evaluation}

Out of 100 participants, 20 were positive (ASCUS 10, LSIL 07, HSIL 03) whereas 80 were negative for Pap smear. 08 out of 20 Pap smear positive cases and 05 out of 80 Pap smear negative cases were found to be malignant on HPE. Sensitivity $61 \%$, Specificity $86 \%$, Positive Predictive Value $40 \%$ and Negative Predictive Value 93\% (Table 6).

Table 7: Correlation of VIA, colposcopy, and cytology with Histopathology.

\begin{tabular}{|c|c|c|c|}
\hline \multirow{2}{*}{$\begin{array}{l}\text { Cytology/ } \\
\text { VIA/ } \\
\text { colposcopy }\end{array}$} & \multicolumn{3}{|c|}{ Malignancy by HPE } \\
\hline & Positive & Negative & $\begin{array}{l}\text { Sensitivity } 100 \% \\
\text { Specificity }\end{array}$ \\
\hline $\begin{array}{l}\text { Positive } \\
(20)\end{array}$ & 13 & 07 & $\begin{array}{l}91.9 \% \\
\text { Positive }\end{array}$ \\
\hline $\begin{array}{l}\text { Negative } \\
(\mathbf{8 0})\end{array}$ & 0 & 80 & $\begin{array}{l}\text { predictive value } \\
65 \%\end{array}$ \\
\hline Total (100) & 13 & 87 & $\begin{array}{l}\text { Negative } \\
\text { predictive value } \\
100 \%\end{array}$ \\
\hline
\end{tabular}

\section{Combination of Pap smear, VIA and colposcopy}

On evaluation of all the modalities namely Pap smear, VIA and colposcopy, total 20 out of 100 were positive either in one or more modalities. Out of 20 positive cases, 13 were subsequently found to be positive on HPE. A correlation of all modalities for evaluation of unhealthy cervix showed $100 \%$ sensitivity.
$65 \%$ whereas negative predictive value approached $100 \%$ (Table 7). 
The overall findings of Pap smear, VIA, Colposcopy and HPE are shown in Table 8.

\section{DISCUSSION}

Unhealthy cervix is a nonspecific sign of multifactorial aetiology. The causal aetiology ranges from normal physiological changes at one spectrum to cervical cancer at the extreme. Benign lesions may be due to ectropion, cervical polyps, cervicitis, cervical fibroids etc. Infections like Chlamydia are associated with eight-fold increase in risk of unhealthy cervix. ${ }^{2}$ It is essential that unhealthy cervix be thoroughly assessed.

Due to various cultural, social, domestic and financial reason, lady of the house at times neglect her own health. Because of multitude of domestic chores her physical wellbeing is relegated to secondary priority. Thus, it becomes imperative that she should be provided a complete work up. ${ }^{3}$

US Preventive services task force (USPSTF) 2019 recommends a pap smear every three year for women in the age group 21-29. For women between 30 to 65 years, screening every three years with cytology alone, every five years with HPV DNA testing alone, or every 5 years with co-testing. ${ }^{4}$

Because of an asymptomatic prodromal stage cervical cancer tends to be identified in later stage. When it has spread to adjacent tissues. At later stages surgical treatment is not gratifying. Radiation and adjuvant chemotherapy are mainly palliative. Because of systemaic side effects often these modalities of treatments are not tolerated well by patients. The outcome remains suboptimal in locally advanced cervical cancer. 5

Pap smear is a rapid and fairly easy outpatient screening modality. It is based on principal of exfoliative cytology. The shed cells from cervix are collected and evaluated. It has sensitivity of $55 \%$ and specificity of $75 \%$ with Positive predictive value of about $88 \%$ and negative predictive value of $33 \%$. The sensitivity of this investigative modality remains low in numerous studies including ours. ${ }^{6,7}$ This mandates that it needs to be augmented with other tests to make early detection of cervical cancer more certain. Because of this, there has been criticism of reliability of annual Pap smear. It is widely believed that a single smear carry an unspecified but significant margin of error. ${ }^{8}$ To avoid missing out on detection of early cancer USPSTF recommended an age specific yearly pap screening. ${ }^{3}$

Newer innovations include liquid based cytological screening. These yield a statistically significant decrease in number of unsatisfactory smears. This is not commonly available in a developing country like ours. ${ }^{9}$
In a prospective analytic study by Papa Dasari et al, inflammatory Pap smear report was the commonest finding. ${ }^{10}$ Dense inflammation on Pap smear can conceal early invasive disease and needs to be more thoroughly or repeatedly evaluated. In our study, 32 patient showed inflammatory Pap smear report and 18 of these had early preinvasive disease.

Colposcopy is a screening tool for cervical cancer. The principle is to evaluate cervix under magnification to look for occult preinvasive lesions. A thorough colposcopic assessment as per American society for colposcopy and cervical pathology (ASCCP) includes visual assessment under adequate magnification and illumination with biopsy of suspicious area. Timely diagnosis allows conservative management in early stage disease. ${ }^{11}$ Use of green filter to more extensively study the branching patters evolved over time.

Our study showed a very high negative predictive value (95\%) of a normal colposcopy result. It means a normal picture on colposcopy rules out suspicion of occult disease in suspicious cytology/Pap smear report to a large extent. David Luesley et al showed a similar result in colposcopic evaluation of 1927 patients. $^{12}$

VIA was a boon in screening especially in resource poor countries like ours. Its utility is further enhanced due to its ease, low cost and real time screening. ${ }^{13}$ Alone as an evaluation modality to detect early, occult disease VIA has a high specificity $(89 \%)$ and negative predictive value $(93 \%) .^{14}$

In various studies, VIA has higher sensitivity than Pap smear to detect early or preinvasive lesions. ${ }^{15}$ In our study also correlation of VIA with Pap smear gives higher sensitivity.

As we see, individually these assessment modalities are good but lack in specificity. Combining all these modalities for screening will lead to improvement in specificity and sensitivity. This will eliminate false negative and improve upon true positive.

\section{Limitation of the study}

Study sample size is less. Larger studies may be undertaken to have more statistically significant results.

\section{CONCLUSION}

One of the essential responsibilities for a gynaecologist, as a health care provider is to provide preventive health care. Unhealthy cervix is a multifactorial entity. It requires to be investigated with all the vigour as it may harbour an intraepithelial neoplasm or an unsuspected invasive carcinoma.

Though exfoliative cytology is a good screening procedure, it has some limitations. Colposcopy 
overcomes some of these by localizing and demarcating the extent of lesion as well as providing reasonable idea of underlying pathology. Diagnostic efficacy of complimentary cytology and colposcopy is such that very few lesions will escape detection.

The use of cytology, VIA and colposcopy together therefore constitutes an ideal screening modality for evaluation of unhealthy cervix. Finally, since histopathology is the cornerstone of diagnosis, with a colposcopic directed biopsy one can very accurately determine the pathology by sampling the most abnormal area visualised at colposcopy.

\section{ACKNOWLEDGMENTS}

Authors would like to thank all the nursing staff, PG residents, interns and supportive staffs. The authors are really grateful to all the participating ladies who consented to be part of the study.

Funding: No funding sources

Conflict of interest: None declared

Ethical approval: The study was approved by the Institutional Ethics Committee

\section{REFERENCES}

1. Cohen PA, Jhingran A, Oaknin A, Denny L. Review Cervical Cancer. The Lancet. 2019;393(10167):16982.

2. Singh V, Sehgal A, Satyanarayana L, Gupta MM, Parashari A, Chattopadhya D. Clinical presentation of gynecologic infections among Indian women.Obstet Gynecol 1995;85(2):215-9.

3. Pimple SA, Mishra GA. Global strategies for cervical cancer prevention and screening. Minerva Ginecologica. 2019;71(4):313-20.

4. Screening for cervical cancer: Recommendation statement. US Preventive Services Task Force. American Family Physician. 2019;99:4.

5. Naga Ch, Gurram L, Chopra S, Mahantshetty U. The management of locally advanced cervical cancer. Current opinion in Oncology. 2018;30(5):323-9.
6. Nkwabong E, Laure I, Badjan B, Sando Z. Pap smear accuracy for the diagnosis of cervical precancerous lesions. Trop Doct. 2019;49(1):34-9.

7. Akhter S, Bari A, Hayat Z. Variability study between Pap smear, Colposcopy and Cervical Histopathology Findings. Journal of Pakistan Medical Association. 2015;65(12).

8. Koss LG. Editorial. The attack on annual Pap smear. Acta Cytologica. 2017;61:338-44.

9. Pankaj S. Comparison of conventional Pap smear and liquid based cytology: A study of cervical cancer screening at a tertiary care centre in Bihar. Indian $\mathbf{J}$ Cancer. 2018; 55(1):80-3.

10. Dasari P, Rajathi S, Kumar SV. Colposcopic evaluation of cervix with persistent inflammatory Pap smear: A prospective analytical study. Cytojournal. 2010;5(7):16.

11. Michelle J. ASCCP Colposcopy standards: Role of Colposcopy, Benefits, Potential Harms and Terminology for colposcopic Practice. J Low Genital Tract Dis. 2017;21(4):223-9.

12. Luesley D, Downey G. Value of normal colposcopy after an abnormal cervical smear report. J Low Genit Tract Dis. 2009;13(1):33-7.

13. Hegde D, Shetty H, Shetty PK, Rai S. Diagnostic value of acetic acid comparing with conventional Pap smear in the detection of colposcopic biopsy proved CIN. J Cancer Res Ther. 2011;7(4):454-8.

14. Ahmed M, Noohet, El-Sayed M, Mohamed, El-Alfy Y. Visual Inspection of Cervix with Acetic Acid as a screening modality for cervical cancer. J Low Genit Tract Dis. 2015;19(4):340-4.

15. Vahedpoor Z, Behrashi M, Khamehchian $T$, Abedzadeh-Kalahroudi M, Moravveji A, MohmadiKartalayi M. Comparison of the diagnostic value of the VIA and Pap smear in cervical cancer screening. Taiwan J Obstet Gynecol. 2019;58(3):345-8.

Cite this article as: Patil D, Pathak B. Combined use of cytological, visual and colposcopic examination for evaluation of unhealthy cervix and their histopathological correlation. Int J Reprod Contracept Obstet Gynecol 2021;10:2321-5. 